\title{
An energetic correlate between colony size and foraging effort in seabirds, an example of the Adélie penguin Pygoscelis adeliae
}

\author{
Lisa T. Ballance, David G. Ainley, Grant Ballard and Kerry Barton \\ L. T. Ballance (correspondence), Southwest Fish. Sci. Center, NOAA Fisheries, 8604 La Jolla Shores Drive, La Jolla, CA 92037, USA. Email: \\ lisa.ballance@noaa.gov. - D. G. Ainley, H.T. Harvey and Associates, 983 University Avenue, Bldg D, Los Gatos CA 95032, USA. - \\ G. Ballard, PRBO Conserv. Sci., Petaluma, CA 94954, USA and Ecol., Evol. and Behav., School of Biol. Sci., Univ. of Auckland, New \\ Zealand. - K. Barton, Landcare Res. New Zealand Ltd., Private Bag 6, Nelson, New Zealand.
}

\begin{abstract}
Central-place foraging seabirds alter the availability of their prey around colonies, forming a "halo" of reduced prey access that ultimately constrains population size. This has been indicated indirectly by an inverse correlation between colony size and reproductive success, numbers of conspecifics at other colonies within foraging range, foraging effort (i.e. trip duration), diet quality and colony growth rate. Although ultimately mediated by density dependence relative to food through intraspecific exploitative or interference competition, the proximate mechanism involved has yet to be elucidated. Herein, we show that Adélie penguin Pygoscelis adeliae colony size positively correlates to foraging trip duration and metabolic rate, that the metabolic rate while foraging may be approaching an energetic ceiling for birds at the largest colonies, and that total energy expended increases with trip duration although uncompensated by increased mass gain. We propose that a competition-induced reduction in prey availability results in higher energy expenditure for birds foraging in the halo around large colonies, and that to escape the halo a bird must increase its foraging distance. Ultimately, the total energetic cost of a trip determines the maximum successful trip distance, as on longer trips food acquired is used more for self maintenance than for chick provisioning. When the net cost of foraging trips becomes too high, with chicks receiving insufficient food, chick survival suffers and subsequent colony growth is limited. Though the existence of energetic studies of the same species at multiple colonies is rare, because foraging metabolic rate increases with colony size in at least two other seabird species, we suggest that an energetic constraint to colony size may generally apply to other seabirds.
\end{abstract}

Central-place foraging seabirds deplete or reduce the availability of prey around colonies, a fact leading to proposals that the size of such "halos" of available prey ultimately regulates population size (Storer 1952, Ashmole 1963, Birt et al. 1987). An inverse correlation is often evident between colony size and reproductive success, numbers of conspecifics at other colonies with overlapping foraging ranges, and diet quality (Furness and Birkhead 1984, Hunt et al. 1986, Lewis et al. 2001, Forero et al. 2002, Ainley et al. 2003a, 2004, Hipfner et al. 2007). In addition, interference competition for limited prey leads to higher foraging effort (longer trips both in distance and time) for individuals in larger colonies (Lewis et al. 2001, Ainley et al. 2003a, 2004), and slower colony growth (Lewis et al. 2001, Ainley et al. 2004). The proximate mechanism responsible for any of these relationships heretofore has been unknown.

In the southwestern Ross Sea, Antarctica, where about 9\% of the world population of Adélie penguins Pygoscelis adeliae nests in four colonies, we investigated possible mechanisms involved in population regulation by directly measuring the effect of colony size on the energetic cost of foraging. The Ross Sea is the last continental shelf ecosystem on Earth yet to be altered by over-fishing, whaling, wide-spread pollution or introduction of alien invasive species (Ainley 2002a, Smith et al. 2007), and, therefore, offers an unparalleled opportunity to investigate ecological interactions free of direct anthropogenic influence (e.g., Furness 2002, Österblom et al. 2006, 2007, Crawford 2007). Three of the study colonies, all on Ross Island, have been the subject of simultaneous, extensive study (Ainley et al. 2004). Cape Crozier is one of the six largest Adélie penguin colonies in the world, with $\sim 135,000$ breeding pairs. Capes Bird and Royds are orders of magnitude smaller, supporting 47,000 and 4,000 breeding pairs, respectively. Recently, all three colonies have changed in size, but at different rates inverse to colony size, a pattern similar to seabird colonies elsewhere (e.g., Lewis et al. 2001). Size in 1997 compared to 1970 was $260 \%$ greater for Cape Royds, $160 \%$ greater for Cape Bird, and $114 \%$ greater for Cape Crozier (Ainley et al. 2004). None of these colonies are space-limited but the lower growth rate at the largest colony seems to indicate approach of a ceiling, whereas the smallest colony, at least 
through the years of this study, continued to grow unrestrained.

Ainley et al. (2003b) showed that prey quality (diet composition) is equivalent among these colonies, and surmised that prey abundance was as well given the direction of ocean currents; Ainley et al. (2006) found that prey availability is affected for these colonies by the number of foraging whales. Herein, we report field metabolic rate (FMR) and total energy expended (TEE) for time at sea during a foraging trip, measured using doubly-labeled water (Nagy 1980), and relate these measures to colony size. We conclude that colony size is limited proximately by the increasing energetic cost of obtaining food. The intercolony comparison that we were able to accomplish was based on a sample size $(n=40)$, that was much higher than in most other studies using this technique, the limiting factor usually being the cost of doubly-labeled water.

\section{Methods}

\section{Study area}

We conducted research at two colonies on Ross Island $\left(77^{\circ} 30^{\prime} \mathrm{S}, 168^{\circ} \mathrm{W}\right)$ during the reproductive seasons of 1999 and 2001: Cape Crozier (137,135 breeding pairs in 1999) and Cape Bird (45,449 and 21,607 breeding pairs in 1999 and 2001, respectively; Ainley et al. 2004; the lower population size in 2001 was related to more difficult sea-ice conditions, requiring more walking, before and during the egg-laying season). We captured adults leaving the colony, apparently intending to begin a foraging trip. All study birds had at least one chick at the crèche stage.

\section{Collection of samples}

Upon capture of each bird, 1-3 ml of blood was collected from the jugular vein using a 3 -ml syringe and a 22-gauge, $2.5 \mathrm{~cm}$ needle, and $0.95 \mathrm{ml}$ water labeled with 95 atom\% ${ }^{18} \mathrm{O}$ and 99.9 atom $\%{ }^{3} \mathrm{H}$ was injected into the dorsal side of the upper thigh (gluteus maximus and sartorius muscles). This muscle was chosen, rather than any swimming muscles, to avoid compromising swimming ability (Culik and Wilson 1992, Wilson and Culik 1995). Birds were then weighed, fitted with transmitters (Ballard et al. 2001), and put into a cardboard box with ventilation holes for a period of 3-4.75 h to allow for equilibration of the isotopicallylabeled water (Nagy and Obst 1992). Immediately after equilibration, a second blood sample was drawn from the opposite jugular vein and the bird was released. Birds' activity was monitored in the colony by listening for transmitter signals every hour, $10 \mathrm{~min}$ for each bird, around the clock. Upon return from the foraging trip, and in all but one case prior to feeding its chick, the bird was recaptured, the transmitter removed, the bird weighed, and a third blood sample was collected. The bird was then released whereupon, in most cases, it proceeded to immediately feed its chick(s). All field procedures on study animals were approved by the Committee on the Humane use and care of vertebrate animals of H.T. Harvey and Associates.

\section{Sample analysis}

Isotope concentrations in blood samples were measured using mass spectroscopy at the laboratory of Ken Nagy at the University of California, Los Angeles. To convert FMR from $\mathrm{CO}_{2}$ production to heat production we used the following conversion factors: $25.8 \mathrm{~kJ} \mathrm{l}^{-1} \mathrm{CO}_{2}$ for a fish diet (Nagy et al. 1984), and $26.0 \mathrm{~kJ} \mathrm{l}^{-1} \mathrm{CO}_{2}$ for a krill diet (Davis et al. 1989). Diet sampling indicated that during our energetic study, birds were consuming a diet of $20 \%$ fish and $80 \%$ krill at Cape Bird during 1999, 53\% fish and $47 \%$ krill at Cape Bird in 2001, and 64\% fish and 36\% krill at Cape Crozier in 1999 (Ainley et al. 2003b, unpubl. data). Accordingly, we integrated these published values to reflect the assumed diet of our study birds and used conversion factors of 25.96 and $25.86 \mathrm{~kJ} \mathrm{l}^{-1} \mathrm{CO}_{2}$ for Cape Bird penguins in 1999 and 2001, respectively, and $25.87 \mathrm{~kJ} \mathrm{l}^{-1} \mathrm{CO}_{2}$ for Cape Crozier penguins in 1999.

\section{Statistical analysis}

To evaluate the relationship between the energetic costs of foraging and colony size, we built and evaluated two sets of models, one for FMR and one for TEE. Both model sets included the same set of explanatory variables and combinations of these variables: breeding population size (BPS; pairs $\times 10^{4}$ ), colony (COL; Crozier or Bird), mass change during a foraging trip $(\mathrm{g})$, and log foraging trip duration (d; Table 1). All 16 combinations of these variables, including the intercept-only models, were evaluated (Table 2). COL was included to evaluate whether BPS per se (vs. some other characteristic of the colonies) was an important predictor of FMR and TEE.

The models were evaluated using generalized linear modeling in an information theoretic framework, employing the Gaussian link function for FMR and the log-link function for TEE (log-link function provided more normally distributed residuals compared to Gaussian for TEE). Each model was ranked based on its Akaike's information criterion corrected for small sample size (AICc), and relative model weights were calculated (Burnham and Anderson 2002). All models contributing to $90 \%$ of the combined model weight were considered as potentially interesting and examined further to determine if $95 \%$ confidence intervals for estimated coefficients overlapped zero. Residual plots and formal statistical tests (e.g., STATA, version 10.0 sktest; Stata, College Station) indicated that residuals were independent and normally distributed, with homogeneous variances, after log-transforming foraging trip duration, which tended to be skewed towards shorter trips (cf. Ballard et al. 2001).

\section{Results}

Foraging trip duration (FTD) and mass change during a trip varied with colony size and year (Table 1). Mean body mass at the start of foraging trips was similar among colonies and years, but mean mass at the end of trips varied. FMR averaged $5306 \pm 201 \mathrm{~kJ} \mathrm{~d}^{-1}$ (range $2129-$ 8581; Table 1), was dependent on body mass $\left(r^{2}=0.32\right.$, 
Table 1. Mean \pm SE (range) of mass, trip duration, and energetic costs of a foraging trip, as well as breeding population size of the colony for 40 Adélie penguins investigated during two years on Ross Island, Antarctica.

\begin{tabular}{|c|c|c|c|}
\hline & \multicolumn{2}{|c|}{ Cape Bird } & \multirow{2}{*}{$\begin{array}{c}\text { Cape Crozier } \\
\begin{array}{c}1999 \\
n=11\end{array}\end{array}$} \\
\hline & $\begin{array}{l}1999 \\
n=16\end{array}$ & $\begin{array}{c}2001 \\
n=13\end{array}$ & \\
\hline Mass at start of foraging trip (g) & $\begin{array}{l}3800 \pm 82 \\
(3200-4350)\end{array}$ & $\begin{array}{l}3785 \pm 77 \\
(3125-4300)\end{array}$ & $\begin{array}{l}3878 \pm 89 \\
(3313-4325)\end{array}$ \\
\hline Mass at end of foraging trip (g) & $\begin{array}{l}4084 \pm 112 \\
(3350-4750)\end{array}$ & $\begin{array}{l}4417 \pm 146 \\
(3675-5500)\end{array}$ & $\begin{array}{l}4258 \pm 183 \\
(3450-5150)\end{array}$ \\
\hline Mass change during foraging trip (g) & $\begin{array}{l}+284.4 \pm 71.7 \\
(-100-+750)\end{array}$ & $\begin{array}{l}+632.7 \pm 131.8 \\
(0-+1550)\end{array}$ & $\begin{array}{l}+380.4 \pm 162.3 \\
(-774-+1275)\end{array}$ \\
\hline Foraging trip duration $(\mathrm{d})$ & $\begin{array}{l}3.38 \pm 0.30 \\
(1.90-6.68)\end{array}$ & $\begin{array}{l}1.35 \pm 0.10 \\
(0.75-1.88)\end{array}$ & $\begin{array}{l}3.41 \pm 0.36 \\
(1.79-5.01)\end{array}$ \\
\hline Field metabolic rate $\left(\mathrm{kJ} \mathrm{d}^{-1}\right)$ & $\begin{array}{l}5248 \pm 216 \\
(3555-7103)\end{array}$ & $\begin{array}{l}4991 \pm 468 \\
(2129-8581)\end{array}$ & $\begin{array}{l}5761 \pm 355 \\
(3803-7433)\end{array}$ \\
\hline Total energy expended (kJ) & $\begin{array}{l}17,768 \pm 1803 \\
(10,702-38,063)\end{array}$ & $\begin{array}{l}6531 \pm 573 \\
(2195-10,458)\end{array}$ & $\begin{array}{l}20,162 \pm 2772 \\
(6800-37,211)\end{array}$ \\
\hline Breeding population size (pairs; Ainley et al. 2004) & 45,449 & $21,607 *$ & 137,135 \\
\hline
\end{tabular}

*Barton et al., unpubl. data.

$\mathrm{F}=17.564, \mathrm{P}<0.001)$ and, for all but two birds, exceeded that predicted from allometric equations (Nagy et al. 1999; Fig. 1). FMR was a function of breeding population size (BPS, Table 1) and mass change during a foraging trip. The strongest explanatory model included positive effects of BPS ( $\hat{\beta}=78.472 ; 95 \%$ CI: $2.201-154.742)$ and mass change $(\hat{\beta}=1.209$; $95 \%$ CI: $0.397-2.021)$, and had twice as much support as the closest model that did not include BPS (Table 2). The second best model included BPS, mass change and COL, but the 95\% CI for both BPS and COL included zero; the combined model weight for models including BPS was 0.555 compared with 0.433 for those including COL, indicating that BPS was the more influential predictor of FMR. All FMR models including mass change ranked higher than those without, and FMR was positively correlated with mass change $\left(\mathrm{r}^{2}=0.15, \mathrm{~F}=\right.$ 6.627, $\mathrm{P}=0.014$ ), meaning that birds that worked harder per unit of time ended up gaining more mass than those with lower metabolic rates.

TEE averaged $14,774 \pm \forall 1392 \mathrm{~kJ}$ (range 2195-38,063; Table 1) and was a function of BPS, FTD, and mass change during that trip. The best model indicated positive effects of BPS $(\hat{\beta}=0.011 ; 95 \%$ CI: 0.001-0.021), FTD $(\hat{\beta}=1.12$; 95\% CI: $1.01-1.24)$, and mass change $(\hat{\beta}<0.00195 \% \mathrm{CI}$ : $0.0001-0.0003)$, with $40 \%$ of the total model weight (Table 2). However, the second-best model competed closely, with $36 \%$ of the total model weight, and substituted COL for BPS (and also included FTD and mass change) with confidence intervals not including zero for any term (Cape Bird 10\% lower TEE than Cape Crozier; 95\% CI: $1-19 \%)$. Overall, models including BPS performed slightly better than those including COL $(53 \%$ vs. $48 \%$ of total model weights when combined). The third-strongest model was the global model (BPS, COL, FTD, mass change), but estimates of effect for both BPS and COL included zero, and the model weight was only $1 / 3^{\text {rd }}$ that of the next strongest. In this model, FTD and mass change both positively impacted TEE, but the effect of mass change was very small (FTD: $\hat{\beta}=1.11$; 95\% CI: $0.96-1.25$; mass change: $\hat{\beta}<0.001 ; 95 \%$ CI: $0.0001-0.0003)$. Not surprisingly, but in contrast to results for FMR, all models of TEE
Table 2. Model selection results for effects of breeding population size (BPS), colony (COL; categorical variable), mass change during a foraging trip (MC), and trip duration (TD) on field metabolic rate (FMR) and total energy expended (TEE) during a foraging trip.*

\begin{tabular}{|c|c|c|c|c|}
\hline & $\mathrm{AICc}$ & $\triangle \mathrm{AICC}$ & AICwi & $K$ \\
\hline \multicolumn{5}{|l|}{ A) FMR: } \\
\hline$B P S+M C$ & 680.311 & 0.000 & 0.234 & 3 \\
\hline $\mathrm{BPS}+\mathrm{MC}+\mathrm{COL}$ & 681.079 & 0.768 & 0.159 & 4 \\
\hline $\mathrm{MC}+\mathrm{COL}$ & 681.495 & 1.184 & 0.129 & 3 \\
\hline $\mathrm{FTD}+\mathrm{MC}$ & 681.809 & 1.498 & 0.111 & 3 \\
\hline MC & 682.138 & 1.828 & 0.094 & 2 \\
\hline $\mathrm{BPS}+\mathrm{FTD}+\mathrm{MC}$ & 682.169 & 1.858 & 0.092 & 4 \\
\hline $\mathrm{FTD}+\mathrm{MC}+\mathrm{COL}$ & 682.661 & 2.350 & 0.072 & 4 \\
\hline $\mathrm{BPS}+\mathrm{FTD}+\mathrm{MC}+\mathrm{COL}$ & 683.659 & 3.348 & 0.044 & 5 \\
\hline BPS & 686.258 & 5.948 & 0.012 & 2 \\
\hline intercept only & 686.351 & 6.041 & 0.011 & 1 \\
\hline $\mathrm{COL}$ & 686.524 & 5.445 & 0.015 & 2 \\
\hline FTD & 687.992 & 6.913 & 0.007 & 2 \\
\hline $\mathrm{BPS}+\mathrm{COL}$ & 688.543 & 7.464 & 0.006 & 3 \\
\hline $\mathrm{BPS}+\mathrm{FTD}$ & 688.599 & 7.520 & 0.005 & 3 \\
\hline $\mathrm{TD}+\mathrm{COL}$ & 688.775 & 7.696 & 0.005 & 3 \\
\hline $\mathrm{BPS}+\mathrm{COL}+\mathrm{TD}$ & 690.967 & 9.888 & 0.002 & 4 \\
\hline \multicolumn{5}{|l|}{ B) TEE: } \\
\hline $\mathrm{BPS}+\mathrm{TD}+\mathrm{MC}$ & 741.446 & 0.000 & 0.404 & 4 \\
\hline $\mathrm{COL}+\mathrm{TD}+\mathrm{MC}$ & 741.691 & 0.245 & 0.358 & 4 \\
\hline $\mathrm{BPS}+\mathrm{COL}+\mathrm{TD}+\mathrm{MC}$ & 743.849 & 2.403 & 0.122 & 5 \\
\hline $\mathrm{TD}+\mathrm{MC}$ & 743.983 & 2.537 & 0.114 & 3 \\
\hline $\mathrm{COL}+\mathrm{TD}$ & 753.355 & 11.909 & 0.001 & 3 \\
\hline $\mathrm{BPS}+\mathrm{TD}$ & 753.359 & 11.913 & 0.001 & 3 \\
\hline $\mathrm{BPS}+\mathrm{COL}+\mathrm{TD}$ & 755.821 & 14.375 & 0.000 & 4 \\
\hline TD & 756.880 & 15.434 & 0.000 & 2 \\
\hline $\mathrm{BPS}+\mathrm{COL}+\mathrm{MC}$ & 821.557 & 80.111 & 0.000 & 4 \\
\hline $\mathrm{BPS}+\mathrm{COL}$ & 822.243 & 80.797 & 0.000 & 3 \\
\hline BPS & 833.659 & 92.213 & 0.000 & 2 \\
\hline $\mathrm{BPS}+\mathrm{MC}$ & 835.731 & 94.285 & 0.000 & 3 \\
\hline $\mathrm{COL}$ & 837.170 & 95.724 & 0.000 & 2 \\
\hline $\mathrm{COL}+\mathrm{MC}$ & 839.443 & 97.997 & 0.000 & 3 \\
\hline intercept only & 841.249 & 99.803 & 0.000 & 1 \\
\hline$M C$ & 843.372 & 101.926 & 0.000 & 2 \\
\hline
\end{tabular}

*BPS reported as pairs $\times 10^{-4}$, MC reported in grams, TD reported as In (foraging trip duration) in days. Total sample size for FMR and $\mathrm{TEE}=40$ Adélie penguins studied on Ross Island, Antarctica. Models ranked according to Akaike's information criterion adjusted for small sample sizes (AICC); AICc, $\triangle \mathrm{AICC}, \mathrm{AICC}$ weights and number of parameters $(k)$ are given for each model. 
containing FTD ranked higher than models without, whereas mass change was not as consistently selected, and usually had a very weak effect. Therefore, although TEE increased with FTD $\left(\mathrm{r}^{2}=0.88, \mathrm{~F}=286.571, \mathrm{P}<0.001\right.$; Fig. 2), compensation for longer trips in the form of increased mass gain (cf. Weimerskirch et al. 1997) was not evident.

\section{Discussion}

\section{Intraspecific variation in FMR}

Debate exists about the importance of intraspecific differences (or lack thereof) in FMR. Some species seem to have a relatively invariant rate of energy expenditure, regardless of environmental conditions (Obst et al. 1995, Golet et al. 2000), but other species do not (Montevecchi et al. 1992). FMR is known to vary by latitude, weather, reproductive stage and/or effort, food availability, and activity mode (Ellis and Gabrielsen 2002). Perhaps the single most relevant factor affecting FMR is the allocation of time among various activities (Birt-Friesen et al. 1989, Chappell et al. 1993). Differing rates of energy expenditure for birds engaged in travel, prey capture, or resting at sea or on a colony, can cause FMR values within the same species to vary substantially, so, ideally, intraspecific comparisons of FMR should control for activity.

FMR has been measured using doubly-labeled water for Adélie penguins at sea at the same reproductive stage in this and three other studies (Green and Gales 1990, Chappell et al. 1993, Culik and Wilson 1992), a fourth measured birds at a slightly earlier breeding stage (Nagy and Obst 1992). Resulting values can be remarkably similar, yet the difference between the two extremes is $1641 \mathrm{~kJ} \mathrm{~d}^{-1}$, roughly $30 \%$ of mean FMR for this species as a whole (Table 3). To our knowledge, colony size has not previously been suggested as a factor affecting FMR, but the positive relationship between the two is clear (Table 2, Fig. 3), and the one exception to this pattern (Nagy and Obst 1992) comes from a study where the authors suspected their FMR values may have been artificially elevated. In fact, the two colonies from which the highest FMR values were obtained are among the six largest colonies of this species in the world, each containing $\geq 120,000$ breeding pairs (Esperanza and Cape Crozier; cf. Woehler 1993).

We wondered whether the pattern observed in Adélie penguins was evident in other colonial seabird species. We found research results based on doubly-labeled water for the same species at multiple sites and/or multiple years for nine other species: Gentoo penguin P. papua (Davis et al. 1989, Gales et al. 1993), little penguin Eudyptula minor (Costa et al. 1986, Gales and Green 1990), wandering albatross Diomedea exulans (Adams et al. 1987, Shaffer et al. 2001), Leach's storm-petrel Oceanodroma leucorhoa (Ricklefs et al. 1986, Montevecchi et al. 1992), black-legged kittiwake Rissa tridactyla (Gabrielsen et al. 1987, Golet et al. 2000, Jodice et al. 2006), common murre Uria aalge (Cairns et al. 1990, Gabrielsen 1996), thick-billed murre U. lomvia (Croll 1990), black guillemot Cepphus gryle (Roby and Ricklefs 1986, Mehlum et al.1993), and least auklet Aethia pusillus (Roby and Ricklefs 1986, Obst et al. 1995). In most

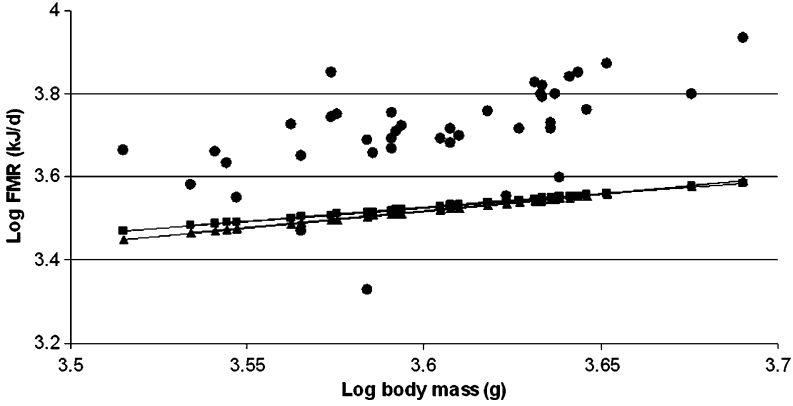

Figure 1. Field metabolic rate (FMR) as a function of body mass for 40 Adélie penguins studied on Ross Island, Antarctica $\left(\mathrm{r}^{2}=\right.$ $0.32, \mathrm{~F}=17.564, \mathrm{P}<0.001)$. The predicted FMR for these same birds using allometric equations for Sphenisciformes (triangles), and all marine birds (squares) is also shown.

of these cases FMR was reported as a value that integrated all activities together, or, in one case, FMR was measured during different stages of reproduction for the same species. The often dramatic differences in rate of energy expenditure for birds engaged in flight, prey capture, or resting at sea or on a colony, can cause FMR values for individuals within the same species to vary widely. So, it is potentially misleading to compare FMR values without knowledge of the activity in which measured birds were engaged.

The following were the only three examples in which the energetics of foraging was separated from integrated measures of daily metabolic rate. Although the differences are subtle, for at least two of the three, Leach's storm-petrel and least auklet, at-sea FMR does increase with colony size (Table 4). For the third, little penguin, available data on colony size are not sufficient for confirmation (Table 4).

Although not directly comparable to our study for the reasons just reviewed, instructive is a recent study on blacklegged kittiwakes at two colonies in Prince William Sound, Alaska (Jodice et al. 2006). Breeders in a small colony (1,500 pairs) were able to increase daily energy expenditure (DEE) in order to take advantage of increased prey availability during one of the study years. In contrast, breeders at the largest colony in the region, five times larger than the small colony (7,500 pairs) and already foraging much farther from the colony than were birds from the smaller colony (Ainley et al. 2004), were not able to increase

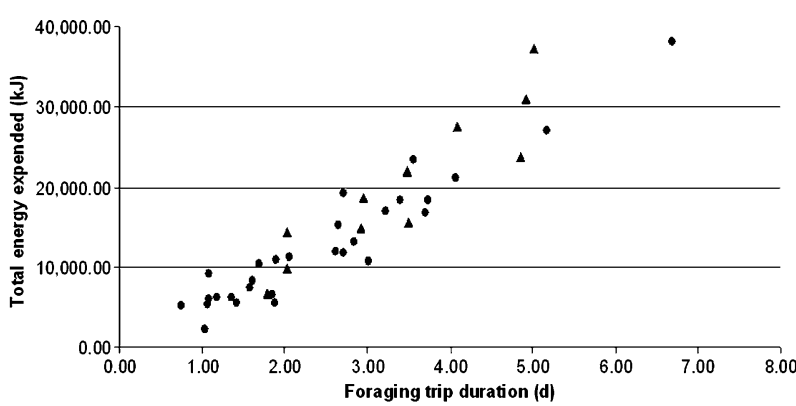

Figure 2. Total energy expended as a function of foraging trip interval for 40 Adélie penguins studied on Ross Island, Antarctica $\left(r^{2}=0.88, F=286.571, P<0.001\right)$. Triangles represent Cape Crozier penguins $(\mathrm{n}=11)$; circles represent Cape Bird penguins $(\mathrm{n}=29)$. 
Table 3. A comparison of energetic costs of a foraging trip during chick provisioning, measured using doubly-labeled water methods, for Adélie penguins at five colonies.

\begin{tabular}{|c|c|c|c|c|c|c|}
\hline Location (sample size) & $\begin{array}{l}\text { Mean at-sea field metabolic } \\
\text { rate }(\mathrm{kJ} / \text { day })\end{array}$ & $\begin{array}{l}\text { Colony size } \\
\text { (no. breeding pairs) }\end{array}$ & Mean mass $\pm \mathrm{SE}(\mathrm{kg})$ & Latitude $\left({ }^{\circ} \mathrm{S}\right)$ & Reproductive stage & FMR/BMR range ${ }^{a}$ \\
\hline $\begin{array}{l}\text { Torgersen Island, Antarctic } \\
\text { Peninsula }(n=16)^{1}\end{array}$ & 4120 & $\begin{array}{l}2,750 \\
\text { (in } 7 \text { colonies) }\end{array}$ & $\begin{array}{l}4.01 \\
(S D=0.24)^{b}\end{array}$ & 64.7 & Chicks crèching & $2.3-3.9$ \\
\hline $\begin{array}{l}\text { Torgerson Island, Antarctic } \\
\text { Peninsula }(n=8)^{2}\end{array}$ & $5605^{b}$ & $14,170^{3}$ & Not specified ${ }^{d}$ & 64.7 & $\begin{array}{l}\text { Eggs just hatched or } \\
\text { adults brooding }\end{array}$ & $3.3-5.5^{c}$ \\
\hline Cape Bird $(\mathrm{n}=29)^{\mathrm{e}}$ & 5133 & $35,732^{3}$ & $4.01 \pm 0.07^{f}$ & 77.5 & Chicks crèching & $2.9-4.8$ \\
\hline Cape Bird $(n=1)^{4}$ & 5186 & $\begin{array}{l}21,607 \\
45,449\end{array}$ & 4.28 & 77.5 & Chicks crèching & $2.7-4.5$ \\
\hline $\begin{array}{l}\text { Cape Crozier }(\mathrm{n}=11)^{\mathrm{e}} \\
\text { Esperanza Bay, Antarctic } \\
\text { Peninsula }(\mathrm{n}=8)^{5}\end{array}$ & $\begin{array}{l}5761 \\
5676\end{array}$ & $\begin{array}{l}137,135 \\
123,850^{3}\end{array}$ & $\begin{array}{l}4.07 \pm 0.12^{f} \\
4.23 \pm 0.12\end{array}$ & $\begin{array}{l}77.5 \\
63.4\end{array}$ & $\begin{array}{l}\text { Chicks crèching } \\
\text { Chicks crèching }\end{array}$ & $\begin{array}{l}3.2-5.3 \\
3.0-5.0\end{array}$ \\
\hline
\end{tabular}

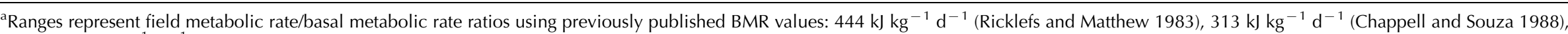
and $266.4 \mathrm{~kJ} \mathrm{~kg}^{-1} \mathrm{~d}^{-1}$ (Kooyman et al. 1976) corrected for body mass of birds in each FMR study.

${ }^{\mathrm{b}} \mathrm{SE}$ was not published.

${ }^{c}$ Authors suggested that this value may have been elevated due to disturbance effects prior to the measurement period, or a shortage of krill swarms in the vicinity.

dMean mass of 11 birds, including the 8 in this group, was $3.81 \mathrm{~kg}(\mathrm{SD}=0.27)$.

'This study.

Mean represents the average of before- and after-trip mass.

${ }^{1}$ Chappell et al. 1993.

${ }^{2}$ Nagy and Obst 1992.

${ }^{3}$ Ainley 2002b.

${ }^{4}$ Green and Gales 1990

${ }^{5}$ Culik and Wilson 1992. 


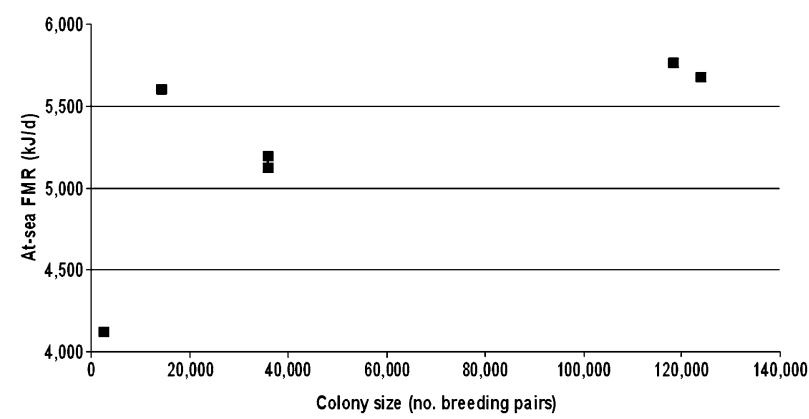

Figure 3. At-sea FMR as a function of colony size for Adélie penguins as measured in five different studies. Data and references are given in Table 3 .

their energy expenditure further. By increasing DEE breeders in the small colony increased nesting success, something which pairs in the larger colony were unable to do in spite of the increase in absolute prey abundance. This finding is consistent with the results we report here.

\section{An energetic constraint to colony size?}

We propose that the positive correlation between at-sea FMR and colony size is due to differences in prey availability (amount or access) induced by intraspecific competition - the larger the colony, the greater the alteration of prey availability, and the higher the rate of energy expenditure necessary to capture prey (Fig. 4). Supporting this hypothesis is, again, the study of blacklegged kittiwakes in Prince William Sound (Ainley et al. 2003a, Jodice et al. 2006), where the frequency of schools of herring Clupea harengus (kittiwake prey) near to the surface increases with distance from the colony, and is also higher near to smaller colonies (see also Lewis et al. 2001 who found the same for gannet Morus bassanus colonies). Also in support are results from our Ross Island study in which penguins increasingly alter their foraging behavior as the breeding season progresses particularly in the case of the larger Cape Crozier colony (Ainley et al. 2004, 2006). As chicks grow and increase food demand, adults dive deeper (Ballard et al. unpubl. data) and forage farther from the colony, and Cape Crozier penguins, presumably by force of numbers, exclude birds from smaller colonies (Cape Bird and nearby Beaufort Island) from their expanding foraging area (Ainley et al. 2004, 2006).

How high can FMR go? The ratio of FMR to Basal Metabolic Rate (BMR), sometimes referred to as sustained metabolic scope, has been suggested to represent an energetic ceiling when FMR is time-averaged and measured for animals maintaining constant body mass whose metabolism is fueled by food intake (Peterson et al. 1990). FMR/BMR values are known to range from 1.5 to 5.0 for 37 species (5 ectothermic vertebrates, 13 birds, and 19 mammals, including endurance athletes in competition;

Table 4. Intraspecific comparisons of at-sea field metabolic rate (FMR) for seabird species measured with doubly-labeled water, at multiple sites, and controlling for breeding stage.

\begin{tabular}{|c|c|c|c|c|c|}
\hline $\begin{array}{l}\text { Species (foraging range, } \\
\mathrm{km} \text { ) }\end{array}$ & $\begin{array}{l}\text { Mean at-sea } \\
\text { FMR }\left(k J d^{-1}\right)\end{array}$ & $\begin{array}{l}\text { Colony size (no. } \\
\text { breeding pairs) }\end{array}$ & $\begin{array}{c}\text { Mean } \\
\text { mass } \pm S E(g)\end{array}$ & $\begin{array}{l}\text { Latitude of } \\
\text { study sites }\end{array}$ & $\begin{array}{l}\text { Breeding } \\
\text { stage }\end{array}$ \\
\hline \multirow[t]{2}{*}{$\begin{array}{l}\text { Little penguin } \\
(15-30))^{9,2,3}\end{array}$} & $\begin{array}{l}986-1209^{4} \\
n=2\end{array}$ & $13,000^{1}$ & $1076 \pm 3.5$ & $38.5 \mathrm{~S}$ & Pre-breeding \\
\hline & $\begin{array}{l}2030^{5} \\
\mathrm{n}=18\end{array}$ & $2,015-19,955^{6}$ & $1074^{\mathrm{b}}$ & $40.4 \mathrm{~S}$ & Courtship \\
\hline \multirow[t]{2}{*}{$\begin{array}{l}\text { Leach's storm } \\
\text { petrel }(>200)^{7}\end{array}$} & $\begin{array}{l}123^{8} \\
n=8\end{array}$ & $86,000^{9}$ & $45^{\mathrm{b}}$ & $44.6 \mathrm{~N}$ & Rearing chick \\
\hline & $\begin{array}{l}161^{10} \\
n=12\end{array}$ & $309,313^{9}$ & $46.6^{\mathrm{b}}$ & $46.9 \mathrm{~N}$ & $\begin{array}{l}\text { Incubation/rearing } \\
\text { chick }\end{array}$ \\
\hline \multirow[t]{3}{*}{$\begin{array}{l}\text { Least auklet } \\
(5-56)^{6}\end{array}$} & $\begin{array}{l}310^{11} \\
\mathrm{n}=3\end{array}$ & $87,500^{12}$ & $78.8 \pm 2.0$ & ca. $60.6 \mathrm{~N}^{12}$ & Rearing chicks \\
\hline & $\begin{array}{l}320^{11,13} \\
n=24\end{array}$ & $125,000^{14}$ & $83.5^{b}$ & $56.6 \mathrm{~N}$ & Rearing chicks \\
\hline & $\begin{array}{l}330^{11} \\
\mathrm{n}=7\end{array}$ & $265,500^{12}$ & $78.6 \pm 1.9$ & ca. $63.7 \mathrm{~N}^{12}$ & Rearing chicks \\
\hline
\end{tabular}

${ }^{a}$ Colonysize is equal to the total number of breeding pairs at the study colony plus the total number breeding within the maximum reported foraging range of that colony. In some cases, colony size corresponding to the date of FMR measurements were unavailable.

${ }^{\mathrm{b}} \mathrm{SE}$ was not published.

${ }^{1} \mathrm{P}$. Dann, unpubl. data.

${ }^{2}$ Klomp and Wooller 1988.

${ }^{3}$ Weavers 1992.

${ }^{4}$ Costa et al. 1986.

${ }^{5}$ Gales and Green 1990.

${ }^{6}$ Oil dpill response atlas: www.thelist.tas.gov.au

${ }^{7}$ Steele and Montevecchi 1994.

${ }^{8}$ Ricklefs et al. 1986.

${ }^{9} \mathrm{~J}$. Chardine, pers. comm.

${ }^{10}$ Montevecchi et al. 1992.

${ }^{11}$ Obst et al. 1995.

${ }^{12}$ Sowls et al. 1978.

${ }^{13}$ Roby and Ricklefs 1986.

${ }^{14}$ Hickey and Craighead 1977. 

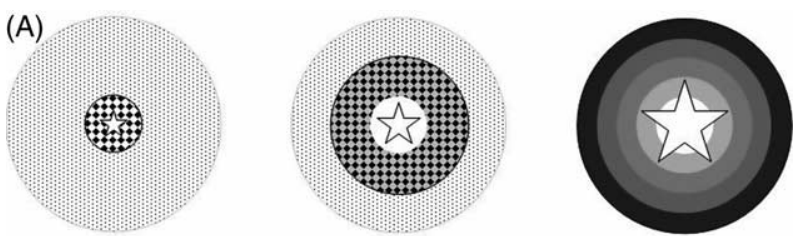

(B)

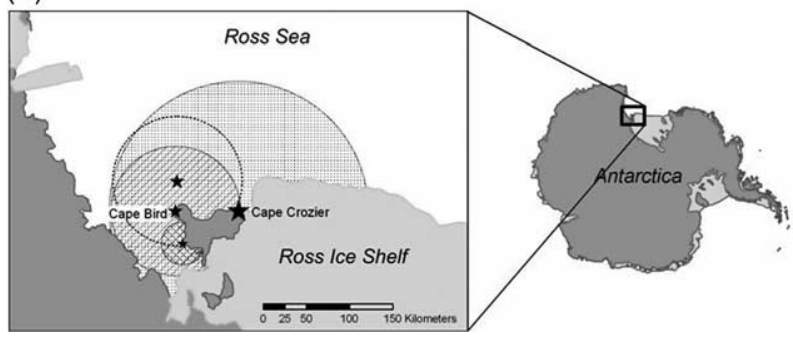

Figure 4. (A) Hypothesized relationship between energetic constraint, colony size, and reproductive season. Central stars represent colonies of different sizes. Fine stippling indicates foraging area within energetic limit, but not used. Outer circles represent energetic limit to foraging distance. Shading represents time of reproductive season (darker is later). At small colony, individuals forage close to colony throughout season; a large portion of energetically available foraging area remains unused. At medium-sized colony, individuals forage close to colony early in season and farther away later in season due to depletion or alteration of prey availability, but some energetically available foraging area remains unused. At colony of maximum size, individuals forage progressively farther from colony through season, ultimately reaching energetic limit. The density of birds supported by the maximum foraging area directly determines the upper limit to colony size. (B) Study colonies and nearby Adélie penguin colonies (stars). Star size represents relative size of breeding populations (Ainley 2002b). Semi-circular areas around each colony represent hypothetical, modeled foraging 'halos' (maximum area utilized), based on the observed foraging ranges of penguins from these colonies (using radio and satellite telemetry; Ainley et al. 2004, 2006).

Peterson et al. 1990), and from 1.8 to 4.8 for seabirds. FMR/BMR ratios are also used to compare energetic effort for specific activities, including walking, swimming, and flying (Ellis and Gabrielsen 2002). The mean of at-sea FMR/BMR ratios for 11 species of seabirds is $3.78 \pm 1.59$ (Birt-Friesen et al. 1989).

We calculated similar ratios using the at-sea FMR values for Adélie penguins in this and four other studies, and the three published values that we found for BMR (Table 3). Because FMR increases with colony size, so too does the FMR/BMR ratio. What is instructive is the absolute value of the ratio, well within the expected range if calculated using the highest BMR value (Ricklefs and Matthew 1983), but ranging as high as 5.5 and 5.0 or greater for birds from the largest two colonies if calculated using the lowest BMR value (Kooyman et al. 1976). Whether or not these values represent energetic ceilings, and whether or not Adélie penguins can sustain higher FMR/BMR effort, is debatable (see also Drent and Daan 1980). What is noteworthy is that these values are among the highest measured for seabirds at sea.

We propose that the positive relationships between colony size, presumed consequent alteration of prey availability, and FMR lead to a constraint on colony size and we believe the Cape Crozier penguins are near that limit (Fig. 4). By increasing FTD (a proxy for trip distance), a bird may somewhat escape the prey-depleted halo. These longer trips incur a higher TEE (as TEE increases linearly with trip duration, Fig. 2). Most important, there is no compensation for longer trips in the form of increased mass gain nor more food fed to chicks, we believe because on the longer trips adults may begin to digest their food load during the return (Ainley et al. 1998). Unlike king penguins Aptenodytes patagonica, which make weeks-long trips and which have mechanisms to inhibit digestion (GauthierClerc et al. 2000), evidence is contrary to this in Adélie penguins (Wilson and Culik 1991). The latter can forestall digestion only until stomach contents warm to body temperature; otherwise, on long trips they bring back less food owing to increased digestion of the food load (summarized in Ainley et al. 1998). At that distance where the costs, in the form of no increase (or a decrease) in food load despite an increase in TEE, outweigh the benefits of foraging outside the halo, FTD is at a maximum.

Colony size, therefore, may be directly determined by the total number of birds that can successfully rear chicks (who survive subsequent to fledging) by foraging within the radius defined by maximum trip duration (and closely correlated energetic expenditure). Greater difficulty, and related consequences, in finding food near to a colony will lead birds to breed elsewhere (Danchin et al. 1998). Involved, of course, is the degree to which the parents use up extra time that when food is greatly available provides them with an appreciable cushion (Zador and Piatt 1999, Enstipp et al. 2006).

Because FMR appears to increase with colony size in at least two other species of seabirds (Table 4), we suggest that this energetic constraint to colony size, through a densitydependent relationship, may apply to seabirds in general as well as potentially to other colonial species. Implicit in this is the assumption that in the absence of seabird colonies (and other predators), the ocean would everywhere exhibit equal prey abundance and availability. Included among the species for which the relationship is evident is a stormpetrel, which further maximizes its foraging range by having the ability to render the food captured to high energy oil. We predict that the relationship we hypothesize would be most extreme among species that carry food to their young in their bill.

For a given species, there could be regional differences in the ceiling as functions of species' flight and food-storage capabilities (cf. very long duration trips by storm-petrels vs short ones by alcids and small penguins), as well as attributes of food abundance, which in modern times has been altered profoundly in most areas by over-fishing and other direct anthropogenic influences (e.g. Halpern et al. 2008; see also references in Introduction). In fact, in the case of the Adélie penguin the few (five) colonies larger than that at Cape Crozier are all located in areas where cetaceans and in some cases finfish have been extirpated; in our study area abundant cetaceans and fish predators help penguins to reduce food supply and/or availability (Ainley et al. 2004, 2006, 2007, Ballance et al. 2006, Ainley and Blight 2009). Recently, Ainley and Hyrenbach (2009) found that in the north-central California Current, where a significant decline in productivity and zooplankton and fish biomass has 
been documented, the majority of seabird species that declined (four of six) are those that acquire prey by diving, i.e. the most energetically demanding mode of feeding and therefore the species most likely to reach their energetic limits with a curtailment of prey. Of further relevance, the declines involved the world's largest colonies of two of these diving species - pigeon guillemot Cepphus columba and Cassin's auklet Ptychoramphus aleuticus - and of a third non-diving species, western gull Larus occidentalis; included as well among diving species, sooty shearwater Puffinus griseus, had been the most abundant seabird in the system. This provides something of a test of our proposal concerning colony size and energetic costs of foraging.

Acknowledgements - We thank S. Webb, T. Dorr, and S. Heath for efforts in the field, K. Nagy, C. Vleck, T. Reidarson, D. Croll, and T. Bucher for consultation on field methods, and D. Cairns, J. Chardine, D. Croll, J. Croxall, P. Dann, G. Gabrielsen, R. Gales, T. Gaston, I. Jones, F. Mehlum, W. Montevecchi, J. Piatt, D. Roby, and E. Woehler for unpublished information. K. Dugger helped with statistical insights. M. Hauber, T. Gaston, K. Hamer, T. Piersma and two anonymous reviewers provided valuable and detailed comments on our paper. This research was supported logistically by the US Antarctic Program and financially by the Office of Polar Programs, National Science Foundation (OPP 0125608, 0440643), and the Southwest Fisheries Science Center of the National Oceanic and Atmospheric Administration; conclusions reported herein are not those of these agencies. PRBO contribution \#1632.

\section{References}

Adams, N. J., Brown, C. R. and Nagy, K. A. 1986. Energy expenditure of free-ranging wandering albatrosses (Diomedea exulans). - Physiol. Zool. 59: 583-591.

Ainley, D. G. 2002a. The Ross Sea, Antarctica, where all ecosystem processes still remain for study, but maybe not for long. - Mar. Ornithol. 30: 55-62.

Ainley, D. G. 2002b. The Adélie penguin, bellwether of climate change. - Columbia Univ. Press, New York.

Ainley, D. G. 2007. Letter response to Ken Frank et al. 'The ups and downs of trophic control in continental shelf ecosystems'. - Trends Ecol. Evol. 22: 444-445.

Ainley, D. G. and Blight., L. K. 2009. Ecological repercussions of historical fish extraction from the Southern Ocean. - Fish Fisheries 10: 13-38.

Ainley, D. G. and K. D. Hyrenbach. 2009. Long and short-term factors affecting seabird population trends in the California Current System 1985-2006. - Prog. Oceanogr., in press. [PLEASE update if possible]

Ainley, D. G., Ballard, G. and Dugger, K. M. 2006. Competition among penguins and cetaceans reveals trophic cascades in the Ross Sea, Antarctica. - Ecology 87: 2080-2093.

Ainley, D. G., Ballard, G., Barton, K. J., Karl, B. J., Rau, G. H., Ribic, C. A. and Wilson, P. R. 2003b. Spatial and temporal variation of diet within a presumed metapopulation of Adélie penguins. - Condor 105: 95-106.

Ainley, D. G., Ford, R. G., Brown, E. D., Suryan, R. M. and Irons, D. B. 2003a. Prey resources, competition, and geographic structure of kittiwake colonies in Prince William Sound. - Ecology 84: 709-723.
Ainley, D. G., Ribic, C. A., Ballard, G., Heath, S., Gaffney, I., Karl, B. J., Barton, K. J., Wilson, P. R. and Webb, S. 2004. Geographic structure of Adélie penguin populations: overlap in colony-specific foraging areas. - Ecol. Monogr. 74: 159-178.

Ainley, D. G., Wilson, P. R., Barton, K. J., Ballard, G., Nur, N. and Karl, B. J. 1998. Diet and foraging effort of Adélie penguins in relation to pack-ice conditions in the southern Ross Sea. - Polar Biol. 20: 311-319.

Ashmole, N. P. 1963. The regulation of numbers of tropical oceanic birds. - Ibis 103b: 458-473.

Ballance, L., Pitman, R.L., Hewitt, R. P., Siniff, D. B., Trivelpiece, W. Z., Clapham, P. J., and Brownell, R. L., Jr. 2006. The removal of large whales from the Southern Ocean: evidence for long-term ecosystem effects? - In: Estes, J. A., DeMaster, D. P., Doak, D. E., Williams, T. E. and Brownell, R. L., Jr. (eds). Whales, whaling and ocean ecosystems. Univ. California Press, Berkeley, pp. 215-230.

Ballard, G., Ainley, D. G., Ribic, C. A. and Barton, K. R. 2001. Effect of instrument attachment and other factors on foraging trip duration and nesting success of Adélie penguins. - Condor 103: 481-490.

Birt, V. L., Birt, T. P., Goulet, D., Cairns, D. K. and Montevecchi, W. A. 1987. Ashmole's halo: direct evidence for prey depletion by a seabird. - Mar. Ecol. Prog Ser. 40: 205-208.

Birt-Friesen, V. L., Montevecchi, W. A., Cairns, D. K. and Macko, S. A. 1989. Activity-specific metabolic rates of freeliving northern gannets and other seabirds. - Ecology 70: 357-367.

Burnham, K. P. and Anderson, D. R. 2002. Model selection and multimodel inference: a practical information-theoretic approach. Second Ed. - Springer-Verlag, New York.

Cairns, D. K., Montevecchi, W. A., Birt-Friesen, B. L. and Macko, S. A. 1990. Energy expenditures, activity budgets, and prey harvest of breeding common murres. - Stud Avian Biol. 14: 84-92.

Chappell, M. A. and Souza, S. L. 1988. Thermoregulation, gas exchange, and ventilation in Adélie penguins (Pygoscelis adeliae). - J. Comp Physiol. B 157: 783-790.

Chappell, M. A., Shoemaker, V. H., Janes, D. N., Maloney, S. K. and Bucher, T. L. 1993. Energetics of foraging in breeding Adélie penguins. - Ecology 74: 2450-2461.

Costa, D. P., Dann, P. and Disher, W. 1986. Energy requirements of free ranging little penguin, Eudyptula minor. - Comp. Biochem. Physiol. 85: 135-138.

Crawford, R. J. M. 2007. Food, fishing and seabirds in the Benguela upwelling system. - J. Ornithol. 148: S253-S260.

Croll, D. A. 1990. Diving and energetics of the thick-billed murre, Uria lomvia.-PhD Diss., Univ. California, San Diego.

Culik, B. M. and Wilson, R. P. 1992. Field metabolic rates of instrumented Adélie penguins using double-labeled water. - J. Comp. Physiol. B 162: 567-573.

Danchin, E., Bouilinier, T. and Massot, M. 1998. Conspecific reproductive success and breeding habitat selection: implications for the study of coloniality. - Ecology 79: 2415-2428.

Davis, R. W., Croxall, J. P. and O’Connell, M. J. 1989. The reproductive energetics of gentoo (Pygoscelis papua) and macaroni (Eudyptes crysolophus) penguins at South Georgia, South Atlantic Ocean. - J. Anim. Ecol. 58: 59-74.

Drent, R. H. and Daan., S. 1980. The prudent parent: energetic adjustments in avian breeding. - Ardea 68: 225-252.

Ellis, H. I. and Gabrielsen, G. W. 2002. Energetics of free-ranging seabirds. - In: Schreiber, E. A. and Burger, J. (eds). Biology of marine birds. CRC Press, Boca Raton, pp. 359-408. 
Enstipp, M. R., Daunt, F., Wanless, S., Humphreys, E. M., Hamer, K. C., Benvenuti, S. and Grémillet, D. 2006. Foraging energetics of North Sea birds confronted with fluctuating prey availability. - In: Boyd, I. L., Wanless, S., Camphuysen, C. J. (eds). Top predators in marine ecosystems; Symp. Zool. Soc. London. Cambridge Univ. Press, pp. 191210.

Forero, M. G., Tella, J. L., Hobson, K. A., Bertellotti, M. and Blanco, G. 2002. Conspecific food competition explains variability in colony size: a test in Magellanic penguins. - Ecology 83: 3466-3475.

Furness, R.W. 2002. Management implications of interactions between fisheries and sandeel-dependent seabirds and seals in the North Sea. - ICES J. Mar. Sci. 59: 261-269.

Furness, R.W. and Birkhead, T.R. 1984. Seabird colony distributions suggest competition for food supplies during the breeding season. - Nature 311: 655-656.

Gabrielsen, G. W. 1996. Energy expenditure of breeding common murres. - Can. Wildl. Serv. Occ. Pap. 91: 49-58.

Gabrielsen, G. W., Mehlum, R. and Nagy, K. A. 1987. Daily energy expenditure and energy utilization of free-ranging black-legged kittiwakes. - Condor 89: 126-132.

Gales, R. and Green, B. 1990. The annual energetics cycle of little penguins (Eudyptula minor). - Ecology 71: 2297-2312.

Gales, R., Green, B., Libke, J., Newgrain, K. and Pemberton, D. 1993. Breeding energetics and food requirements of gentoo penguins (Pygoscelis papua) at Heard and Macquarie Islands. - J. Zool. Soc. Lond. 231: 125-139.

Gauthier-Clerc, M., Le Maho, Y., Clerquin, Y., Drault, S. and Handrich, Y. 2000. Ecophysiology: penguin fathers preserve food for their chicks. - Nature 408: 928-929.

Golet, G. H., Irons, D. B. and Costa, D. P. 2000. Energy costs of chick rearing in black-legged kittiwakes (Rissa tridactyla). - Can. J. Zool. 78: 982-991.

Green, B. and Gales, R. P. 1990. Water, Sodium, and energy turnover in free-living penguins. - In: Davis, L. S. and Darby, J. T. (eds). Penguin biology. Academic Press, San Diego, pp. 245-268.

Halpern, B. S., Walbridge, S., Selkoe, K. A., Kappel, C. V., Micheli, F., D’Agrosa, C., Bruno, J. G., Casey, K. S., Ebert, C., Fox, H. E., Fujita, R., Heinemann, D., Lenihan, H. S., Madin, E. M. P., Perry, M. T., Selig, E. R., Spalding, M., Steneck, R. and Watson, R. 2008. A global map of human impact on marine ecosystems. - Science : 948 319: 952.

Hickey, J. J. and Craighead, F. L. 1977. A census of seabirds on the Pribilof Islands. - In: Environmental assessment of the Alaskan continental shelf. Annual reports of principal investigators, Vol. 2. National oceanic and atmospheric administration, Boulder, pp. 96-195.

Hipfner, J. M., Charette, M. R. and Blackburn, G. W. 2007. Subcolony variation in breeding success in the tufted puffin (Fratercula cirrhata): association with foraging ecology and implications. - Auk 124: 1149-1157.

Hunt, G. L. Jr., Eppley, Z. A. and Schneider, D. C. 1986. Reproductive performance of seabirds: the importance of population and colony size. - Auk 103: 306-317.

Jodice, P. G. R., Roby, D. D., Suryan, R. M., Irons, D. B., Turco, K. R., Brown, E. D., Thedinga, J. F. and Henk Visser, G. 2006. Increased energy expenditure by a seabird in response to higher food abundance. - Mar. Ecol. Prog. Ser. 306: 283-293.

Klomp, N. I. and Wooller, R. D. 1988. Diet of little penguins, Eudyptula minor, from Penguin Island, western Australia. - Aust. J. Mar. Fresh. Res. 39: 633-639.

Kooyman, G. L., Gentry, R. L., Bergmann, W. P. and Hammel, H. T. 1976. Heat loss in penguins during immersion and compression. - Comp. Biochem. Physiol. 54A: 75-80.
Lewis, S., Sherratt, T. N., Hamer, K. C. and Wanless, S. 2001. Evidence of intra-specific competition for food in a pelagic seabird. - Nature 412: 816-819.

Mehlum, F., Gabrielsen, G. W. and Nagy, K. A. 1993. Energy expenditure by black guillemots (Cepphus grille) during chickrearing. - Col. Waterbirds 16: 45-52.

Montevecchi, W. A., Birt-Friesen, V. L. and Cairns, D. K. 1992. Reproductive energetics and prey harvest of Leach's stormpetrels in the northwest Atlantic. - Ecology 73: 823-832.

Nagy, K. A. 1980. CO2 production in animals: analysis of potential errors in the doubly labeled water method. - Amer. J. Physiol. 238: R466-R473.

Nagy, K. A. and Obst, B. S. 1992. Food and energy requirements of Adélie penguins (Pygoscelis adeliae) on the Antarctic Peninsula. - Physiol. Zool. 65: 1271-1284.

Nagy, K. A., Girard, I. A. and Brown, T. K. 1999. Energetics of free-ranging mammals, reptiles, and birds. - Ann. Rev. Nutr. 19: $247-277$.

Nagy, K. A., Siegfried, W. R. and Wilson, R. P. 1984. Energy utilization by free-ranging jackass penguins, Spheniscus demersus. - Ecology 65: 1648-1655.

Obst, B. S., Russell, R. W., Hunt, G. L. JR., Eppley, Z. A. and Harrison, N. M. 1995. Foraging radii and energetics of least auklets (Aethia pusilla) breeding on three Bering Sea islands. - Physiol. Zool. 68: 647-672.

Österblom, H., Casini, M., Olsson, O. and Bignert, A. 2006. Fish, seabirds and trophic cascades in the Baltic Sea. - Mar. Ecol. Prog Ser. 323: 233-238.

Österblom, H., Hansson, S., Larsson, U., Hjerne, O., Wulff, F., Elmgren, R. and Folke, C. 2007. Human-induced trophic cascades and ecological regime shifts in the Baltic Sea. - Ecosystems 10: 877-889.

Peterson, C. C., Nagy, K. A. and Diamond, J. 1990. Sustained metabolic scope. - Proc. Natl. Acad Sci. 87: 2324-2328.

Ricklefs, R. E. and Matthew, K. K. 1983. Rates of oxygen consumption in four species of seabird at Palmer Station, Antarctic Peninsula. - Comp. Biochem Physiol. 74A: 885-888.

Ricklefs, R. E., Roby, D. D. and Williams, J. B. 1986. Daily energy expenditure by adult Leach's storm-petrels during the nesting cycle. - Physiol. Zool. 59: 649-660.

Roby, D. D. and Ricklefs, R. E. 1986. Energy expenditure in adult least auklets and diving petrels during the chick-rearing period. - Physiol. Zool. 59: 661-678.

Shaffer, S. A., Costa, D. P. and Weimerskirch, H. 2001. Behavioural factors affecting foraging effort of breeding wandering albatrosses. - J. Animal Ecol. 70: 864-874.

Smith, W. O., Jr., Ainley, D. G. and Cattaneo-Vietti, R. 2007. Marine ecosystems: the Ross Sea. - Phil. Trans. Roy. Soc. B 362: 95-111.

Sowls, A. L., Hatch, S. A. and Lensink, C. J. 1978. Catalog of Alaskan seabird colonies. - Biol. serv. progr., U.S. dep. interior, Anchorage.

Steele, D. H. and Monevecchi, W. A. 1994. Leach's storm-petrels prey on lower mesopelagic (Mysidacea and Decapoda) crustaceans: possible implications for crustacean and avian distributions. - Crustaceana 66: 212-218.

Storer, R. W. 1952. A comparison of variation, behavior and evolution in the seabird genera Uria and Cepphus. - Univ. Calif. Publ .Zool. 52: 121-222.

Weavers, B. W. 1992. Seasonal foraging ranges and travels at sea of little penguins Eudyptula minor, determined by radio tracking. - Emu 91: 302-17.

Wilson, R. P. and Culik, B. M. 1995. Energy studies of free-living seabirds-do injections of doubly-labelled water affect gentoo penguin behavior. - J. Field Ornithol. 66: 484-491. 
Weimerskirch, H., Cherel, Y., Cuenot-Chaillet, F. and Ridoux, V. 1997. Alternative foraging strategies and resource allocation by male and female wandering albatrosses. - Ecology 78: 2051-2063.

Wilson, R. P. and Culik., B. M. 1991. The cost of a hot meal: facultative specific dynamic action may insure temperature homeostasis in post-ingestive endotherms. - Comp. Biochem. Physiol. 100: 151-154.
Woehler, E. J. 1993. The distribution and abundance of Antarctic and Subantarctic penguins. - Scientific committee for Antarctic research, Scott polar res. inst., Cambridge.

Zador, S. G. and Piatt, J. F. 1999. Time-budgets of common murres at a declining and increasing colony in Alaska. - Condor 101: 149-152. 